\title{
Ascites Fluid Sample
}

National Cancer Institute

\section{Source}

National Cancer Institute. Ascites Fluid Sample. NCI Thesaurus. Code C159203.

A biospecimen of ascitic fluid. 